\title{
Association of Anxiety and Teacher Expectation among High School Students in Jakarta
}

\author{
Nadya Desita Siregar ${ }^{1}$, Wuri Prasetyawati ${ }^{2^{*}}$, Mita Puspita Sary ${ }^{3}$ \\ ${ }^{1,2,3 .}$ Faculty of Psychology, Universitas Indonesia, Depok, Indonesia \\ *E-mail: nadya.desita@ui.ac.id
}

\begin{abstract}
Adolescents as students spend their times more in school, so interaction with people in school could affect their socio-emotional development. In achieving academic achievement, the teacher has a significant role for them. Teacher gives expectation based on students' behavior and attitude in class. Based on previous studies, different teacher expectation towards students could be one of the risk factors that trigger common adolescents' mental health problem, anxiety. This study tried to investigate the relationship between anxiety and perceived teacher expectation on high school students in Jakarta. This study used The Hopkins Symptom Checklist (HSCL-25) to measure anxiety and Expectations for Student Achievement (ESA) Related Teacher Practices subscale to measure perceived teacher expectation. This one-shot study conducted in five high schools in five district areas of Jakarta and 764 first grade high school students participated. The result indicated that there is no relationship between anxiety and perceived teacher expectation on high school students in Jakarta. This finding revealed that teacher's expectation is not the risk factor of high school students' high anxiety in Jakarta. Therefore, other school-based risk factors should be investigated in the future to figure out the threat of adolescents' mental health.
\end{abstract}

Keywords: adolescent; anxiety; jakarta; teacher expectation

\section{Introduction}

Adolescence is a transition period of human development involving changes in physical, cognitive, emotion, and social aspect of different social, cultural, and economic situation (Papalia \& Martorell, 2014). Adolescence is also a period when self-esteem, intimacy with other people, and ability to be autonomous are developing rapidly. Not only development period on a lot of aspects, but adolescence is also a full-of-risk period, which mental health problems symptoms are potential to increase in this period (Kovacs \& Devlin as cited in Karevold, 2008). Mental health problems symptoms on adolescent usually divided into two forms, emotional problems (internalizing) and behavior problems (externalizing). Most common emotional issues on adolescent are depression and anxiety. Meanwhile, an example of behavior problems is conducted problem. Among those two problems, emotional problems are the most commonly happen in adolescents. Moreover, adolescents nowadays are well-known to be more fragile, more rigid, and feeling overwhelmed rather than previous generation (Schrobsdorff, 2016).

Schwartz (as cited in Schrobsdorff, 2016) found that most common mental health problem in kids and teenagers in the recent years is anxiety. Meanwhile ten years ago (2006) most common mental health problem was depression. Anxiety is a mental health problem for kids and teenagers that most common and most often shown on school-situation (Hanie \& Stanard, 2009; Ingul, Klockner, Silverman, \& Nordahl as cited in Hess, 2014). Anxiety can get worse on high school level because students struggle an extreme transition period regarding higher social and academic pressures rather than previous educational level (Henry, Jamner, \& Whalen as cited in Hess, 2014). The transition process from middle school into high school not only can be a unique and challenging period but also can be transition period when a student is on the peak of puberty and experiencing a variety of mental health problems like high anxiety and stress level (Kennelly \& Monrad, 2007). 
Adolescents as high school students who live in big cities such as Jakarta are susceptible to experience mental health problems. Not only as largest metropolitan city in Southeast Asian, but Jakarta is also the most dynamic city that experiencing the most complex urban issues on $21^{\text {st }}$ century (Rukmana, 2016). As the center of most economic activities for Indonesian citizens and other cities around it (Bogor, Depok, Tangerang, Bekasi), complex activities could emerge a lot of problems in urban context and specifically mental health problems. Adolescents in Jakarta also cannot avoid mental health problems that possibly to appear.

Anxiety itself is a situation when someone feels tension, anxious, worry, easy to get angry, and fearful (Mirowsky \& Ross, 2003). Anxiety involves unclear feeling about something, unpleasant, and fearfulness (Santrock, 2012). On school context, adolescent or student who is experiencing anxiety symptoms usually feels anxious or nervous to face their academic challenges. Anxious often followed by the appearance of physical reaction such as sweating and fast heart beating. A student who has anxiety symptoms has some impacts on their daily functioning. Among others are impairment on academic or social performance on school such as poor physical health, academic difficulties, high level of depression, substance use, poor social and interpersonal adjustment and impaired selfcompetence (Rapee, Hudson, \& Schniering; Santrock, 2012).

Three general factors that could influence the emergence or enhancement of psychological distress (Drapeau, Marchand, \& Beaulieu-Prevost, 2012):

1. Sociodemographic factor; or characteristics of someone since birth (e.g., gender, age, and ethnicity) or something that reflects individual's role in the social structure. The most common factor is gender, which previous studies found that higher psychological distress (either depression or anxiety, or both) could be seen more on female rather than male.

2. Stress-related factor; event or life condition that encourage the emergence of stress on individual's well-being or unwanted things in life (Murkowsky \& Ross, 2003).

3. Personal resources factor; resources that individual could use to avoid the emergence of psychological distress (either internal or external personal resource factor). Example for internal is self-esteem and sense of control of an individual. Meanwhile external are such as social network, social support, income, and education.

Adolescents spend most of their time in school; therefore, interaction with people in school could affect adolescents' socio-emotional development (Papalia \& Martorell, 2014). Among all people who adolescent interact with, the teacher has the biggest role for adolescent as a student in the process to achieve academic achievements. Teacher's role is not just about to teach students subjects like math, science, art, etc., but also to give proper affection and attitude for students to increase their motivation to achieve specific academic achievement (Heck \& Williams as cited in Good, 2008).

Student and teacher interaction could emerge some expectation from teacher to each student in the class. Expectation usually expressed by the way teacher treats their students in the class. Therefore, the student more likely to give reaction as the expectation that expressed by their teacher. It's because people, in general, will react to other people based on their hopes and other people's expectation for them (Gursimsek, 1999). In a school context, since the first year of school at any educational level, the student already could perceive different teacher expectation towards their performances or among other students in the class (Gottfredson et al., 1991).

Teacher expectation is a conclusion that teacher made about student's behavior and academic achievement either now or in the future, and also made based on what they know about their student now (Good, 1987). Teacher expectation expressed on teacher's different attitude and behavior towards a student, and also give direct or indirect effects to student's achievement (Brophy \& Good, 1970; Good as cited in Weinstein, Marshall, Bratessani, \& Middlestadt, 1982). Mason and Larimore's study on 1974 (as cited in Braun 1976) showed that teacher form a different level of perception and expectation toward each student based on student's characteristics and probably reflected on their behavior towards the student. Different behavior toward each student could give information to students about expected behavior from the teacher and indirectly could affect student's academic performance, self-concept, and motivation.

A teacher usually expresses their expectation toward a student by their particular behavior (Good \& Brophy as cited in Garcia \& Chun, 2016). Teacher expectation made from student's previous achievements, and students perceive teacher 
expectation by some aspects (Good, 1987; RubieDavis, 2015; Kerman, Kimball, \& Martin as cited in Garcia \& Chun, 2016):

1. How teacher grouping students into low and high achievers

2. Learning experiences that provided by teacher to students

3. Teacher's tendency to believe that student could achieve some specific academic achievements

4. Teacher's trust in themselves about their effectivity to teach

5. Behavior management types in class or school that implemented by teacher in class

6. Responses that teacher provide for student

7. Feedbacks from teacher

8. Teacher's attitude on respecting student; for example, how a teacher could behave politely in class or another situation.

Expectation and pressure to succeed in school from adult or specific teacher toward adolescent in school-age could affect the increasing of anxiety (Melman, Little, \& Akin-Little as cited in Hanie \& Stanard, 2009; Eccles, Wigfield, \& Schiefele; Wigfield et al. as cited in Santrock, 2012). The expectation expressed on more often evaluation, social comparison, and different behavior in class. On high school student, pressure for students to be successful on academic mostly come from the teacher in school. Adolescent or student with anxiety symptoms could also experience difficulty in daily functioning, doing daily task or role in the school environment (Wagner as cited in Hanie \& Stanard, 2009). One of them is to perceive teacher expectation that expressed on behavior toward a student. In this case, it shows that the relationship between anxiety and teacher expectation possible to exist.

Previous research (Tyler \& Boelter, 2008) shows that students on adolescent age reported that high teacher expectation as significant predictor toward cognitive, emotional, and behavioral attachment, and also with academic efficacy or believe toward academic achievement. Therefore, this research is to see the relationship between emotional factor or specifically anxiety symptoms and teacher expectation on high school student in Jakarta, Indonesia. High school is an extreme transition period compares to previous education level. For example, the schoolwork that tends to become more difficult. It makes teacher expectation probably becomes more various, which then influence students' anxiety to increase.

Based on literature review and previous research, researchers expected that anxiety would significantly relate with teacher expectation perceived by adolescents or specifically high school students in Jakarta. We also assumed that there are differences of anxiety and teacher expectation scores based on gender and high or lowperformance group. This research aim is to see the relationship between anxiety and teacher expectation on high school students in Jakarta.

\section{Methods}

Sample. Participants were 764 first grade high school students and between the ages from $15-19$ $(M=15.98)$ in five schools in five urban or administration cities of Jakarta (North Jakarta, Central Jakarta, West Jakarta, East Jakarta, and South Jakarta). Participants were 404 females (52.9\%) and 360 males (47.1\%). The majority of the participants grouped into $35.87 \%$ average performance group (Score: 78.5-81.8) with 274 participants. Then followed by $20.03 \%$ lowperformance group with 153 participants $(55-78)$, $24.47 \%$ high-performance group with 187 participants (82 -96), and the remaining are $19.63 \%$ who didn't fill the score with 150 participants. The classification based on participants' last semester report final score percentile. Multistage sampling was used to choose sample starts from the province, municipality, administration cities, and schools. Schools selected by random sampling (from school list in Jakarta) and representative to each district areas in Jakarta. Selected schools in this study are schools under the ministry of education and culture, both private and public schools. All first-grade students in each school participated in this study.

Research Design. This school-based study is a oneshot study or cross-sectional study, a research design that most suitable to find a prevalence of a phenomenon and only take one-time data sampling (Kumar, 2011).

Instrument and Measurement. Related Teacher Practices subscale from Expectations for Student Achievement (ESA) by Kerman, Kimball, and Martin on 1980 used to measure participant's perceived teacher expectation (Gottfredson, Marciniak, Birdseye, \& Gottfredson, 1995). ESARelated Teacher Practices has a coefficient alpha of 0.78 (Gottfredson et al., 1995) and 0.81 on other 
research (Kerman et al. as cited in Garcia \& Chun, 2016). This study also adapted items scale modification from Tyler \& Boelter (2008)'s study; changed all items' scale into $5=$ always, until $1=$ never. ESA-Related Teacher Practices translated into Bahasa Indonesia through back translation and expert judgment process with coefficient alpha 0.836 .

This study used ten first items of The Hopkins Symptom Checklist (HSCL) - 25 that has been translated into Bahasa Indonesia by Turnip and Hauff (2007) to adopt cultural and language issues. Coefficient alpha of 10 first items HSCL-25 is 0.84 (Derogatis et al., 1974). HSCL-25 has high and accurate predictive level for both anxiety and depression symptoms or as psychological distress as general (Lhewa et al., 2007).

Table 1.

Items in Instrument

\begin{tabular}{lc}
\hline ESA-Related Teacher Practices & Item No. \\
\hline $\begin{array}{l}\text { I am sure what I'm supposed to do in } \\
\text { my class }\end{array}$ & 1 \\
$\begin{array}{l}\text { My teacher gives me enough time to } \\
\text { think before I give an answer }\end{array}$ & 2 \\
$\begin{array}{l}\text { I feel my teacher listens to what I } \\
\text { have to say }\end{array}$ & 5 \\
\hline The Hopkins Symptom Checklist & Item No. \\
(HSCL) - 25* & 1 \\
\hline $\begin{array}{l}\text { Suddenly scared for no reason } \\
\text { Faintness, dizziness, or weakness } \\
\text { Nervousness or shakiness inside }\end{array}$ & 2 \\
\hline$*$ for past last week & 4 \\
\hline
\end{tabular}

Procedure. All participants in this study selected as part of a larger study. After randomizing schools, the administration process took place in each school, and all first-grade students in each school were all participated. Questionnaire booklet used in this study and administrated by the collective administration. After administrated questionnaire booklets to all students in each class, researchers explained about the general instruction. Each booklet has 12 subparts because this study is part of a broader study. There was no time limit to fill the questionnaire, but because the study took two classes time (around 80 minutes in total or 40 minutes for each class), therefore the time given to fill the questionnaire was between 30-70 minutes. After each participant completed the survey, they will get a pack of beverage, snack, and a block-note as a reward.

\section{Results}

Descriptive analyses conducted before correlation and additional analyses. Table 2 shows anxiety and teacher expectation score mean of 764 participants in this study. The cut-off point from the instrument that measures anxiety symptoms on this study is 1.75 (score range from $0-4.00$ ) (Strand, Dalgard, Tambs, \& Rognerud, 2003) This instrument has been widely used in different countries. As previous studies in similar Asian population found 1.75 to be appropriate (Turnip \& Hauff, 2007), therefore this study also adopted this cutoff point in this studyThus, participants' anxiety mean score on this study is considered as high $(\mathrm{M}=>1.75)$. Meanwhile, teacher expectation score mean on this study is deemed to be low because usually based on previous researches that used the same instrument, for example, Tyler and Boetler (2008), have mean score on point 3.00 or specifically 3.88 or 4.00 (score range from $0-4.50$ ).

Table 2.

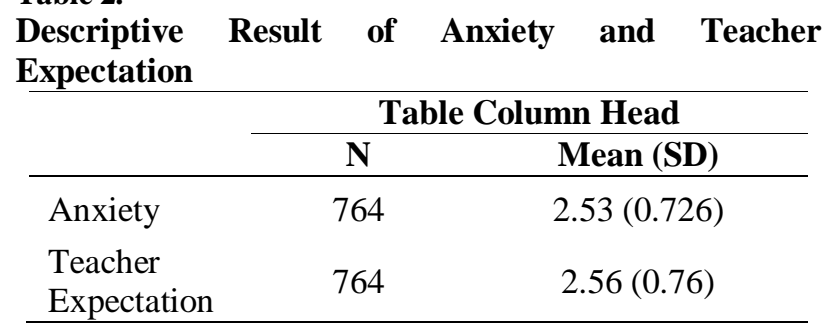

Using Pearson Product Moment to see the relationship between two variables, Table 3 . shows that there is no significant relationship between anxiety and teacher expectation on high school students in Jakarta.

Table 3.

Correlation between Anxiety and Teacher Expectation

\begin{tabular}{lcc} 
& \multicolumn{2}{c}{ Anxiety } \\
\cline { 2 - 3 } & $\boldsymbol{r}$ & $\boldsymbol{P}$ \\
\hline Teacher & -0.020 & 0.575 \\
Expectation & & \\
\hline
\end{tabular}

Additional analyses conducted as could be seen in Table 4 that shows t-test analyses based on demographic data; gender and high-low achievers. There is significant difference between anxiety on male and female participants $(\mathrm{t}=-2.66, \mathrm{p}<0.05)$. Minus on t-test score shows that anxiety score on male participants is significantly lower than anxiety score on female participants. Meanwhile, t-test score between teacher expectation and gender $(t=$ 
$1.165, \mathrm{p}>0.05)$ shows that there is no significant difference between male and female.

The sample of the population divided into high and low achievers participants according to participants' last semester final report score percentile. T-test score on teacher expectation with high and low achiever participants showed that there is no significant difference between high and low ( $\mathrm{t}=$ $1.27, \mathrm{p}>0.05)$. There is also no significant difference on teacher expectation score between high and low achievers participants $(t=1.61, p>$ $0.05)$.

Table 4.

T-test Analyses based on Demographic Data

\begin{tabular}{|c|c|c|c|c|c|c|}
\hline & & $\begin{array}{c}\text { Mean } \\
\text { (SD) }\end{array}$ & $\mathbf{t}$ & df & $\mathbf{N}$ & $\mathbf{P}$ \\
\hline \multirow[t]{4}{*}{ Anxiety } & Male & $\begin{array}{l}2.458 \\
(0.71)\end{array}$ & -2.66 & 762 & 762 & 0.008 \\
\hline & Female & $\begin{array}{l}2.597 \\
(0.72)\end{array}$ & & & & \\
\hline & Low (55-78) & $\begin{array}{c}2.57 \\
(0.68)\end{array}$ & 1.27 & 338 & & 0.205 \\
\hline & High (82-96) & $\begin{array}{c}2.47 \\
(0.70)\end{array}$ & & & & \\
\hline \multirow[t]{4}{*}{$\begin{array}{l}\text { Teacher } \\
\text { Expectatio } \\
n\end{array}$} & Male & $\begin{array}{c}2.59 \\
(6.92)\end{array}$ & 1.165 & 762 & 762 & 0.244 \\
\hline & Female & $\begin{array}{c}2.53 \\
(6.87)\end{array}$ & & & & \\
\hline & Low (55-78) & $\begin{array}{c}2.66 \\
(0.78)\end{array}$ & 1.612 & 338 & & 0.108 \\
\hline & High (82-96) & $\begin{array}{c}2.52 \\
(0.79)\end{array}$ & & & & \\
\hline
\end{tabular}

\section{Discussion and Conclusion}

Discussions. This study indicated that there is no significant relationship between the high and low level of teacher expectation and anxiety on the student. This finding probably because teachers are considered to be students' resources whose help them to achieve in school. Their role is different from social support and emotional support (Drapeau et al., 2012). This finding showed that other factors such as stress-related factor or personal resources factor have more impact on the high level of anxiety on adolescent or high school students in Jakarta nowadays. Individual resources are either internal (e.g., self-esteem, sense of control, etc.) or external (e.g., social network and social support except for teacher).

Compare to previous similar research by Decker et al. (2007) and Tyler \& Boelter (2008); both studies showed that student's perception of teacher expectation is a predictive factor of student's socioemotional functioning and academic attachment on black adolescents in America. Black adolescents in
America perceived high teacher expectation reflecting their desire to be close to the teacher. That's because they view the teacher as their resource to help them succeed in school or socioemotional functioning. Meanwhile, the teacher for participants of this study is not their resource that affects their emotional functioning especially for the emergence of anxiety symptoms. Participant's demographic factor or specific cultural or sociocultural factor could be one of the factors of there's no significant relationship of this study (Drapeau et al., 2012; Rubie-Davis as cited in Good, 2008).

Although there was no significant difference on teacher expectation score between male and female participants, this study found that there was a significant difference on anxiety for both groups. The study found that male groups have lower anxiety scores than female. That happened because socio-demographic factor or individual's characteristic specifically gender is one of the factors of anxiety emergence. In general, psychological distress both depression and anxiety are higher on female rather than male (Drapeau et al., 2012). 
T-test analyses on anxiety and teacher expectation based on high and low achiever participants showed that there are no significant differences in both variables. There's no difference between perceived teacher expectation on both two groups possibly because both had quite a similar perception regarding their teacher expectation (high $=2.66$ and low $=2.52$ ). It might happen because teacher expressed not that different attitude or behavior toward both of the groups or as general to all students. It's also same with anxiety, probably academic achievement is not one of the factors that can make high school students in Jakarta have anxiety symptoms, or other factors have stronger impacts than academic achievement., such as their physical appearance, interaction with people that is not cordial or their domestic skills( Frans-Briggs \& Alikor, 2010)

This study is a part of a more extensive research, so there are a lot of sub-parts (12 parts) items that participants should fill on the questionnaire. So researchers didn't read one by one instruction in every questionnaire's section, every participant was told to read each instruction written in each part. Items quantity and guidance could be the study limitation because there is a big chance of human error; participants don't read the instruction of questionnaire well and could affect the result of each participant scores.

The instrument used in this study to measure teacher expectation is also considered outdated. It is from Gottfredson, Marciniak, Birdseye, and Gottfredson (1995). There is no revision of the instrument both from the authors or other studies after that. Other measurement devices that measure teacher expectation are also the same.

Although there are some limitations of this study, this study also has some strengths. First, the sample of this study is large (764 participants) so the results of each variable should be more stable and representative of population or phenomena. Second, this study used school-based paper and pencil questionnaire data collection. Thus, researchers could control the situation when participants were filling the questionnaire (ecological validity). Third, this study was a part of a larger research, therefore supported by other research on the same area. Last, the data of this study could be one of a prospective study for example for qualitative method research, etc.

According to some research and specifically by Bandura (as cited in Tyler \& Boelter, 2008), self- efficacy on a student is not only could predict academic performance, but also could predict four essential things: mastery experiences, vicarious experiences, social persuasion, and even emotional and physical condition. High teacher expectation could increase self-efficacy or academic-efficacy on students in school. Relationship pattern between those three variables could happen and impacting relationship significance between anxiety and teacher expectation. For example, when someone has high teacher expectation, self-efficacy in the academic field will be higher. Therefore, higher selfefficacy could affect anxiety level on the student which is lower than someone who has lower selfefficacy. So, self-efficacy or academic-efficacy could be a potential variable that moderate relationship between anxiety and teacher expectation.

Conclusions. According to this study hypothesis, result from the study that conducted in five schools in five cities in Jakarta showed that hypothesis null is accepted. It's because there's no significant relationship between the high and low level of teacher expectation with anxiety in each student or participant. After adding some additional analysis on participants' demographic data, result only indicated that there is differences anxiety level between male and female participants, which male participants have a lower level of anxiety rather than females. Future study should explore more about other school-based risk factors that could affect student's anxiety.

\section{References}

Brophy, J. E., \& Good, T. L. (1970). Teachers' communication of differential expectations for children's classroom performance: Some behavioral data. Journal of Educational Psychology, 61(5), 305-374.

Decker, D. M., Dona, D.P., \& Christenson, S. L. (2007). Behaviorally at-risk African American students: The importance of student-teacher relationships for student outcomes. Journal of School Psychology, 45, 83109.

Derogatis, L. R., Lipman, R. S., Rickels, K., Uhlenhuth, E. H., Cori, L. (1974). The Hopkins symptom checklist (HSCL): A self-report symptom inventory. Behavioral Science, 19.

Drapeau, A., Marchand, A., \& Beaulieu-Prevost, D. (2012). Epidemiology of Psychological Distress. Mental Illness - Understanding, Prediction, and Control. 
Frank-Briggs, Angela I \& Alikor, EAD (2010). Anxiety disorder amongst secondary school children in an urban city in Nigeria. International Journal of Biomedical Science. 6 (3). 246 - 251

Garcia, C., \& Chun, H. (2016). Culturally responsive teaching and teacher expectations for Latino middle school students. Journal of Latina/o Psychology, 4(3), 173-187.

Good, T. L. (1987). Two decades of research on teacher expectations: Findings and future directions. Journal of Teacher Education, 38, 32-47.

Good, T. L. (2008). $21^{\text {st }}$-century education: A reference handbook. Los Angeles: SAGE Publications.

Gottfredson, D. C., Marciniak, E. M., Birdseye, A. T., Gottfredson, G. D. (1991). Increasing teacher expectations for student achievement: An evaluation. Retrieved from http://files.eric.ed.gov/fulltext/ED339788.pdf

Gottfredson, D. C., Marciniak, E. M., Birdseye, A. T., Gottfredson, G. D. (1995). Increasing teacher expectations for student achievement. The Journal of Educational Research, 88(3), 155-163.

Gursimsek, I. (1999). Student perceptions of teacher expectations in elementary classrooms. Hacettepe Universitesi Egitim Fakultesi Dergisi, 15, 43-50.

Hanie, E. H., \& Stanard, R. P. (2009). Students with anxiety in the schools. GSCA Journal, 16(1).

Hess, J. (2014). Anxiety prevalence among high school students. Counselor Education Master's Theses. Paper 170.

Karevold, E. (2008). Emotional problems in childhood and adolescence: Predictors, pathways and underlying structure (Dissertation, University of Oslo, 2008). Retrieved from https://www.duo.uio.no/bitstream/handle/10852/1 8433/DUO_126_Karevold.pdf?sequence $=1$

Kennelly, L., \& Monrad, M. (2007). Easing the transition to high school: Research and best practices designed to support high school learning. National High School Center. Retrieved from http://files.eric.ed.gov/fulltext/ED501073.pdf

Kumar, R. (2011). Research Methodology: A step-by-step guide for beginners ( $3^{\text {rd }}$ ed.). London: SAGE Publications Ltd.
Lhewa, D., Banu, S., Rosenfeld, B., \& Keller, A. (2007). Validation of a Tibetan translation of the Hopkins symptom checklist-25 and the Harvard trauma questionnaire. Assessment, 14(3), 223-230. DOI: $10.1177 / 1073191106298876$.

Mirowsky, J., \& Ross, C. E. (2003). Social causes of psychological distress ( $2^{\text {nd }}$ Ed.). New York: Aldine De Gruyter.

Papalia, D. E. \& Martorell, G. (2014). Experience human development $\left(13^{\text {th }}\right.$ ed.). New York: McGraw Hill.

Rubie-Davis, C. (2015). Becoming a high expectation teacher: Raising the bar. New York: Routledge.

Rukmana, D. (2016, October 27). Problems and challenges in Jakarta caused by rapid urbanization. The Velvet Cell. Retrieved from https://www.thevelvetcell.com/blogs/news/proble ms-and-challenges-in-jakarta-caused-by-rapidurbanization\#

Santrock, J.W. (2012). Educational Psychology (5 ${ }^{\text {th }}$ ed.). New York: McGraw Hill.

Schrobsdorff, S. (2016, October 27). Teen depression and anxiety: Why the kids are not alright. TIME. Retrieved from http://time.com/magazine/us/4547305/november7th-2016-vol-188-no-19-u-s/.

Strand, B. H., Dalgard, O. S., Tambs, K., \& Rognerud, M. (2003). Measuring the mental health status of the Norwegian population: A comparison of the instruments SCL-25, SCL-10, SCL-5 and MHI-5 (SF-36). Nord J Psychiatry, 57(2), 114-118.

Turnip, S. S., \& Hauff, E. (2007). Household roles, poverty and psychological distress in internally displaced persons affected by violent conflicts in Indonesia. Soc Psychiatry Psychiatr Epidemiol, 42, 997-1004

Tyler, K. M., \& Boelter, C. M. (2008). Linking black middle school students' perceptions of teachers' expectations to academic engagement and efficacy. The Negro Educational Review, 59(1-2), 2008.

Weinstein, R. S., Marshall, H. H., Brattesani, K. A. (1982). Student perceptions of differential teacher treatment in open and traditional classrooms. Journal of Educational Psychology, 74(5), 678692. 